\title{
American Appeal: Assault Weapons
}

\author{
Nicholas J Kethley* \\ $U S A$ \\ *Corresponding Author: Nicholas J Kethley, USA
}

Today, the public's perception of violence by the use of automatic weapons has the masses in hysteria. Between school and movie theater shootings it is perceived that nobody is safe. Assault weapons can easily be converted to full automatic and wipe out a classroom full of children in seconds. However, there is yet a minority of gun enthusiast in the United States that feel guns (in particular assault weapons) are not part of the problem of gun violence, it is merely the people who use guns that are responsible for the mass atrocities over the last few decades. That being said, this research is not on any political belief on gun control, but instead, on the purchasing and advertising history of these items; specifically assault weapons. This article looks at the selling power assault weapons convey for the U.S. population. This will cover the Vietnam War era into our contemporary time by using newspaper advertisements and stories to profit from the sale of assault weapons. Political debates including automatic weapons are only included as they pertain to manufacturing, distributing and dealing: legally or illicitly. The research delves into the commerce of the gun industry, and why this particular facet of the gun trade blossomed into the market we see appealing to our American culture today.

Our consumer culture in America has a massive effect on our everyday lives. For a minute amount of the population, guns came to symbolize several ideas of American life; independence, power, freedom to name a few. Americans obsession with consumption culture affects everyone including gun enthusiasts who also want bigger, better and faster. From our founding days of the Republic where minute men could be called on to grab their muskets in a moment's notice to fire volleys of individual balls, to machine guns of the early 20th century (which were outlawed for public use), the next evolutionary step in this market was the semi-automatic weapons that acted as machine guns for military usage. Marketed specifically to the politically conservative wing of America starting in the nineteen eighties, the phenomenon has grown to the entire gun owning population. With the splitting of legal hairs gun manufacturers were able to produce military style weapons for normal citizens. With no practical purpose for hunting, target practice or self-defense this research is interested in the fascination they have for everyday Americans.

We as Americans have grown up believing that gun ownership was a traditional way of life. Our nostalgic love obsession with the past has helped the myth permeate from, (Rosenblatt, 2003). ${ }^{1}$

Rosenblatt says:

The image of shoot 'em up America was mainly the invention of Samuel Colt, who managed to convince a malleable 19th century public that no household was complete without a firearm- "an armed society is a peaceful society." . . U Until 1850, fewer than $10 \%$ of U.S. citizens had guns. Only $15 \%$ of violent deaths between 1800 and 1845 were caused by guns. Reputedly wide-open Western towns, such as Dodge City and Tombstone, had strict guncontrol laws; guns were confiscated at the Dodge City limits (Rosenblatt, 2003). ${ }^{2}$

Rosenblatt was making a case for getting rid of guns entirely in America, but his argument gives me information on the past and America's reality during the 19th century. According to Rosenblatt, America at its inception and into the late 19th century was not swallowed whole by a country of gun

\footnotetext{
${ }^{1}$ Roger Rosenblatt, Guns Control Opposing Views, ed. Helen Cothran (New York: Greenhaven Press, 2003), 48.

${ }^{2}$ Rosenblatt, 48 .
} 
loving and gun toting tough guys. That would mean that guns did not even serve the purpose of protecting one's family. People were likely more akin to carrying axes and knives more for protection than anything else. Rosenblatt tells us this fabrication of a love affair with guns in early American history began with a product of the American consumerist movement, id est Samuel Colt. The man is behind the boom in gun production and gun purchasing in America. His idea of a safer America because of guns allowed the market to grow from insignificance outside of the military, to being entrenched in the American psyche as the way of life of our forefathers. So if we buy a gun today we are taken back to the 'good old days.'

According to Harry L. Wilson, the Bureau of Alcohol, Tobacco, and Firearms has maintained a count of the number of firearms produced and imported since 1974. Records prior to that are sketchy; an estimate of 90 million firearms in 1968 is generally accepted. More current estimates suggest that there are at least 200 million firearms in the United States. In addition, the long gun market has shifted somewhat away from shotguns and traditional hunting rifles toward rifles and shotguns more commonly associated with combat use, the so called assault weapons. While we do not know the exact number of these weapons that have been sold, it is obvious from the academic literature and a look at any gun shop, gun show, or gun magazine that these firearms have become more popular. Vizzard notes, for example, in a1960 Gun Digest referenced none of these weapons, but it included more than one hundred types of combat guns by 1993. Still it is unlikely that the average gun owner would possess one(Wilson, 2007). ${ }^{3}$

Wilson's examples bring to light the uncertainty in the gun market. Every other industry is fully regulated from car makers to cigarette companies, but the federal department enacted by Congress to oversee guns in general cannot or is not allowed to calculate the overall sale or production of items that are considered a deadly weapon by everyone. All the Bureau of Alcohol, Tobacco and Firearms can do is predict production and guess how many guns are in America. That leaves no data for assault weapons and society can only make valid judgments based off of secondary work by authors who have studied this area vehemently. There is a silver lining, Wilson points out the almost sudden rise in advertising of assault weapons between 1960 and the early 1990's. This gives us an indication that assault weapons rose in popularity within that time frame.

Most people do not know the difference between "assault rifles" and "assault weapons" and for good reasoning. Assault rifles are military rifles that are fully automatic weapons. According to Gerald D. Robin, "Fully automatic weapons, commonly referred to as machine guns, fire a continuous stream of up to 600 bullets so long as the gun's trigger is depressed"(Robin, 1991). ${ }^{4}$ On the other hand the assault weapon (which my research is about) is a "semi-automatic 'assault-style' weapon which, at any time, could be legally purchased over the counter just as easily as any other rifle or shotgun. The rapid-fire, military style weapons fire one bullet each time the trigger is squeezed and can fire up to 70 rounds of bullets without reloading, which is done automatically"(Robin, 1991)..$^{5}$ Machine guns were made illegal in 1934 after a crime wave of bank robberies that included the likes of John Dillinger, 'Baby Face' Nelson, and Bonnie \& Clyde whom easily purchased them through mail order. Since that time they are only issued legally to military, police or special collectors.

The source of the definition of "assault weapons" is from the Legislative branch of the federal government. When the federal government signed into passage the Brady Bill in 1994 making assault weapons illegal for ten years any one of these following reasons defined a gun as an assault weapon: high rate of fire, large magazine capacity, lethality of ammunition, pistol grips, threaded muzzle, flash suppressors, bayonet mounts, grenade launcher mount, and their easy accessibility to be converted to full automatic (Kopel, 1995). ${ }^{6}$

American television programmers in the early seventies seemed to believe the public would enjoy learning how to build their own machine gun. In the Eureka Times Standard, the North Coast Panorama Complete Television Listing on January 17, 1971 had on its cover a picture of a man

\footnotetext{
${ }^{3}$ Harry L. Wilson, Guns, Gun Control, and Elections: The Politics and Policy of Gun Control, (Lanham, Maryland: Rowman \& Littlefield Publishers Inc., 2007), 48.

${ }^{4}$ Gerald D. Robin, Violent Crime and Gun Control (New Haven: University of New Haven, 1991), 81.

${ }^{5}$ Robin, 81.

${ }^{6}$ David B. Kopel, Guns Who Should Have Them (New York: Prometheus Books, 1995), 161-173.
} 
surrounded by industrial pieces and tools. The headline read as This Week in Panorama: Eureka Man Invents a Machine Gun (Eureka Times Standard, North Coast Panorama Complete Television Listing, 1971). ${ }^{7}$ The man in the photograph is concentrating on piecing together metal to build what looks to be a machine gun. This conveys the impression that the American public has an interest in automatic weapons, and if it is not feasible to buy a machine gun, the assault weapon can fill that void.

The Vietnam War had been America's first television war. Reporters and television crews had never had the up close access that previous wars would allow. War could now be seen on the evening news in color T.V. The newspapers of the time enjoyed showing every picture they could to the public. It allowed the public to view the life and articles of equipment that American warriors would use in combat. The American public would find an appeal for military armaments and clothing. Army/Navy stores sprung up across the country. Surplus military equipment appealed to Americans and became a hot commodity. In Alaska, the Fairbanks Daily News Miner, on March 15, 1972 had a single page devoted to just photographs of the Vietnam War. The largest photo on the top of the page shows a picture with a caption that reads, "Phantom jets make low level pass over camp." The several pictures below it show troop movements and transports. The middle left picture is a close up of a soldier in winter clothes with his entire body covered in extra machine gun ammunition, while he is holding a light machine gun (Fairbanks Daily News Miner, 1972). ${ }^{8}$

Heavy weapons became the hottest trend for the gun industry. Two news articles from the same paper come to mind. The Elyria Chronicle Telegram from Elyria, Ohio on March 12, 1978 reports on the gun enthusiast new love obsession (Chernisky, 1978). ${ }^{\circ}$ In a headline from the front page Heavy Weapons for Sale it allows the reader to inquire about how much this new hobby cost and the ease in which these military style guns can be purchased. The larger the caliber the more expensive they are. According to the article, "A vintage Thompson in good condition could cost about $\$ 3,000$, and special or unfired models might be priced in the five figure category." Ingrams and Thompsons are only two of many machine gun makes in demand, according to the dealers. There are also customers they say for the M-16, the basic Army small arms weapon used in Vietnam; the M-60, a small caliber machine gun fired from a tripod; and an assortment of other machine guns. Some buyers are veterans who used a particular kind of weapon during their service career. Owners of machine guns tend to like to shoot them too- and the operating, as well as the owning, is an expensive hobby, even though some owners prepare their own bullets and re-use the shells several times (Chernisky, 1978). ${ }^{10}$ The article also tells us how good these assault weapons are for investment purposes. Dealers and some collectors believe interest in the weapons is increasing as their investment value rises. "The investment value is fantastic," says Downie, who says that the retail cost of the M-10's has doubled in the last two years. "They're going up in price at such a rate that the return is better than with stocks and bonds," maintains one Elyria gun collector, who stores his Ingram M-10 in a velvet lined violin case (Chernisky, 1978). ${ }^{11}$

The irony of this article is the section talking about President Jimmy Carter and his proposal for increases in annual fees charged for gun dealers. The article says increases could drive many of the dealers out of business, "A dealer licensed to sell machine guns would have to pay a $\$ 750$ yearly fee, compared to the $\$ 200$ annual occupational tax Class III dealers are now required to pay" (Chernisky, 1978). ${ }^{12}$ Today, the market is so successful that any fee the federal government can dream up is insignificant to what is charged for these weapons.

The second article from the Elyria Chronicle Telegram is on page A-3again by Tom Chernitsky titled, He Likes the Machine Gun with or without Silencer. Chernitsky interviews Mickey Downie, owner of Downie\& Associates, a gun sales business in Brecksville Ohio. Chernitsky tells us that the M-10 machine gun is very popular among machine gun enthusiast because it is the most inexpensive one.

\footnotetext{
${ }^{7}$ Eureka Times Standard, North Coast Panorama Complete Television Listing, Eureka, California, January 17, 1971.

${ }^{8}$ Fairbanks Daily News Miner, Fairbanks, Alaska, March 15, 1972.

${ }^{9}$ Tom Chernisky, Heavy Weapons for Sale (Elyria Chronicle Telegram, March 12, 1978, Elyria, Ohio) A-3.

${ }^{10}$ Chernisky, A-3.

${ }^{11}$ Chernisky, A-3.

${ }^{12}$ Chernisky, A-3.
} 
Downie demonstrated that weapon as well as the M-60 and Thompson machine guns in front of the reporter and photographer. When asked why would someone buy one? Because says Downie, "It's an investment and it's part of history" (Chernitsky, 1978). ${ }^{13}$ According to this gun dealer, the only two reasons for owning these guns is the idea that you could make a profit from holding onto them long enough; and they are noteworthy for their use in battle, so owning one means paying homage to a warrior ethos.

In the late 1970's the gun industry affected the toy industry. In the Kingsport Times News on November 13, 1977 there was a page devoted to toys. The headline read as follows "Buy your toys now while selections are most complete." There was a Fisher Price Play School Desk Set, a Pin-ball game and several other toys pictured with prices on them. In the second row was Hasbro's new Ghost Gun for only $\$ 4.90$. The caption read as "The Ghost Gun plugs spooky phantoms without noise danger or missiles." The Ghost Gun was pictured by a young white boy shooting at a picture of a ghost. The Ghost Gun even looks like an assault weapon with sites and pistol grips included (Kingsport Times News, 1977). ${ }^{14}$ In the Alton Telegraph on September 12, 1979 in their toy advertisement section they had a Sting Gun with disc caps for gun, as well as a Ping Pong Pistol(Alton Telegraph, 1979). ${ }^{15}$ These items allow young boys to grow up with the impression of guns in their youth. So when they are older guns become a masculine mode of enjoyment. In the mid 2000's I came across a video game ad for kids from K-mart that was published in the Daily Globe on May 6, 2006(Daily Globe, 2006). ${ }^{16}$ It was next to staples of the gaming world, Mario and Yoshi's Island. The name of this game was simply called Gun. The cover was just a skull and it was available for Gamecube, Playstation 2 and X-Box.

By the 1980's these semi-automatic assault weapons had seen national issues of conversion into fully automatic weapons that made them contraband in the eyes of the federal government. The newspaper article by Alan Montgomery in the Hutchinson News on September 22, 1985 titled, Feds Crack Down on Conversion Kits tells the public how easy it was to build these:

It's possible to build a machine gun in your living room- but federal agents are making it tough to get parts. The Colt AR-15 assault rifle can be converted to an M-16 machine gun by replacing several of its internal parts with a handful of other parts and gadgets ... Most of the conversion parts are available through magazine ads. Others can be found at some of the larger gun shows and on the black market. In June, several national gun magazines stopped carrying sale ads for "drop-in auto sears" which are matchbook sized, steel- plate-and spring devices essential to AR-15 conversions. The ads had told how to order the devices from private manufacturers for about $\$ 70$ each (Montgomery, 1985). ${ }^{17}$

Alan Montgomery also had a second article continued from the front page of the newspaper in the Hutchinson News on September 22, 1985. This was title simply Weapons and followed a gun show near Hutchinson, Kansas. Montgomery had seen one young visitor sporting green combat fatigues and carrying an AR-15A2, casually swung over one shoulder. When interviewed the seventeen year old asked that his address and last name not be published, but he posed for a picture. His first name is Tim. Montgomery interviewed the teenager. Tim said, "I'm into assault weapons, I used to be into 22's. This is my first high-power," Tim said. He brought his rifle to the gun show not because he wanted to sell or trade it, but because he wanted to carry it around he said. He shoots the weapon for enjoyment. When Montgomery asks Tim about the major motion picture Red Dawn that was popular with youths at the time Tim replied, "If something like that did happen, if they landed, I wouldn't be afraid to go out and stop them. I don't like Communist. I think they're the scourge of the earth. You won't find a Communist weapon in my house. I'm all American" (Montgomery, Hutchinson News, 1985). ${ }^{18}$ This teenager is a product of the consumer culture in the 1980's. Ardently against leftist

\footnotetext{
${ }^{13}$ Tom Chernitsky, He Likes the Machine Gun With or Without Silencer (Elyria Chronicle Telegram, March 12, 1978, Elyria, Ohio) A-3.

${ }^{14}$ Kingsport Times News, November 13, 1977, Kingsport, Tennessee.

${ }^{15}$ Alton Telegraph, September 12, 1979, Alton Illinois.

${ }^{16}$ Daily Globe, May 6, 2006, Ironwood, Michigan.

${ }^{17}$ Alan Montgomery, Feds Crack Down on Conversion Kits (Hutchinson News, September 22, 1985, Hutchinson, Kansas) 5.

${ }^{18}$ Alan Montgomery, Weapons (Hutchinson News, September 22, 1985, Hutchinson Kansas) 5.
} 
thinking and adamant about his second degree right to protect his country if a hypothetical invasion by the Russians really did happen, just like in the movie Red Dawn.

Assault weapons caught on big in the United States during the 1980's. Gun magazines in the 1980's would feature a steady stream of favorable reviews of assault weapons. According to Tom Diaz in his publication, Making a Killing: The Business of Guns in America he says in his states that assault weapons are a product of what he calls the Rambo Factor:

Many factors combined to help the emergence of assault weapons in the civilian market during the 1980's. The gun industry capitalized on all of these factors by flooding the market with new designs, and promoting their sale through advertising and gun press puffery. During the 1980's, popular television shows like the A-Team and Miami Vice, and movies like the Rambo series, Commando, and others prominently featured assault weapons. The military service of Vietnam veterans also resulted in familiarity with such weapons among a significant part of the general population (Diaz, 1999). ${ }^{19}$

In addition to the effects assault weapons had on popular culture, Diaz says the most sinister factors boosting their popularity were the parallel emergence during the 1980's of the so-called "survivalist" movement:

This movement encompasses a wide spectrum of thought, but much of it has been closely associated with the political paranoia and extreme racial and cultural views of the far right that eventually mutated into the militia phenomenon of the 1990's . . In general, the theories of these extremists declare that there inevitably will be either widespread collapse of civil order (as in a race war), severe suppression of civil liberties, or both, and they advocate that prudent persons heavily arm themselves for "survival" under such extreme circumstances (Diaz, 1999). ${ }^{20}$

Diaz cites valid points in terms of the survivalist movement. In a 1982 Guns \& Ammo magazine article it listed the "success of military assault rifles in the civilian market, together with the survivalist movement they represent" as one of the "10 unlikeliest ideas in the Shooting Sports Which Have Succeeded." Diaz also cites a 1989 article on the "Top Ten Gun Trends of the Decade" one writer pronounced, "Ten years ago, black guns (assault weapons) were fairly rare. Then interest in survival-oriented items increased tremendously, and these interests included guns." Another Guns \& Ammo writer explained that "to survivalists, these compact carbines combine a wealth of firepower into a small package." Gun magazines during this period carried advertising for "survival knives," for books effusing a generalized nostalgia for the "action of the Vietnam war era, and for military style clothing and gear (Diaz, 1999). ${ }^{21}$ Tom Diaz at the time of writing his book was working for a nonprofit public policy institute working to reduce gun violence. His negative stance about the political right shines through his book. Still his analysis about the survivalist movement is accurate. It had a significant effect on gun enthusiast. Diaz gives more credence to the survivalist movement, but he seems to forget that movies reach a larger fan base than gun magazines. Those television shows and movies that featured machine guns gave the country a taste of the new trend in the gun industry and may have turned more people on to picking up Guns \& Ammo and become hobbyist of assault weapons.

By the 1990's, newspapers in the rugged or more predominantly conservative areas would advertise guns in subtle and banal ways. In the Santa Fe New Mexican on Novermber 12, 1991 there was a page advertisement that caught my eye. The most robust part of the ad was of gym merchandise. The largest picture was of a treadmill with a man using it. A smaller picture was encapsulated inside this bigger picture of a workout machine that can be used for several exercises. To the right on the border of this gym advertisement was two prices and pictured above the prices and caption were gun cabinets. From left to right it read: "\$99.97 Sale Price. Solid pine gun cabinet with etched glass. Holds up to 6 guns. $\$ 179.97$ Our $\$ 199.97$. Steel security gun cabinet holds 12 guns, ammo and

\footnotetext{
${ }^{19}$ Tom Diaz, Making a Killing: The Business of Guns in America (New York: The New Press, 1999), 125.

${ }^{20}$ Diaz, 125.

${ }^{21}$ Diaz, 126.
} 
accessories." The most bizarre part of the add was not the fact that gun cabinets were being sold next to gym merchandise, but at the bottom right hand side of the page was an ad for Disneyland. It said "A Magical Disneyland Christmas" and the infamous Disneyland castle was pictured(Santa Fe New Mexican, 1991). ${ }^{22}$ It was perplexing to say the least. Exercise, guns and Disneyland, all the things an American family needs to stay healthy, protect themselves and enjoy a family vacation all in one page!

The last advertisement I have is from the Hutchinson News from February 3, 1998 in Hutchinson, Kansas. The major caption in the middle of metal furniture reads as follows, "New! Gun Metal Finish." To the left is a small candle stand and text that states, "Gun metal finished wrought iron." Below that is another caption that says, "Magazine rack ornate gun metal wrought iron rack." To the right of the advertisement is a plant stand with, "gun metal finished steel"(Hutchinson News, 1998). ${ }^{23}$ It seemed necessary to show the way advertisers can sell the appeal of guns in furniture being offered to the public. According to advertisers guns are apparently ingrained in people's psyche enough that consumers would want to place an article of furniture in their home because it resembles a gun.

The assault weapon is the gun industries pinnacle of a gun owner's imagination running wild. When a gun owner can shoot bullets with large capacity canisters at his or her beckon call it makes some Americans cringe, but others delighted. Personal beliefs differ greatly in our country. The research shows that cultural perception can change and fringe beliefs can become generally accepted views, this may be a hindrance to any progressive change. The assault weapon's appeal started with war veterans coming home and wanting guns they could feel nostalgic about. Assault weapons then became a symbol of machismo and the survivalist movement to finally becoming socially acceptable enough to be put on furniture and to use online sites like Groupon for affordable yet exciting dates to the gun range. The American appeal of these weapons only seems to be growing with every day that passes.

\section{REFERENCES}

[1] (1977, November 13). Kingsport Times News.

[2] (1979, September 12). Alton Telegraph.

[3] (1991, November 24). Santa Fe New Mexican.

[4] (1998, February 3). Hutchinson News.

[5] (2006, May 6). Daily Globe.

[6] Chernisky, T. (1978, March 12). Heavy Weapons for Sale. Elyria Chronicle Telegram, pp. A-3.

[7] Chernitsky, T. (1978, March 12). He Likes the Machine Gun with or without Silencer. Elyria Chronicle Telegram, pp. A-3.

[8] Diaz, T. (1999). Making a Killing: The Business of Guns in America. New York: The New Press.

[9] Eureka Times Standard, North Coast Panorama Complete Television Listing. (1971). Eureka.

[10] Fairbanks Daily News Miner. (1972). Fairbanks.

[11] Kopel, D. B. (1995). Guns Who Should Have Them. New York: Prometheus Books.

[12] Montgomery, A. (1985, September 22). Hutchinson News. Feds Crack Down on Conversion Kits, p. 5.

[13] Montgomery, A. (1985, September 22). Hutchinson News. Weapons, p. 5.

[14] Robin, G. D. (1991). Violent Crime and Gun Control. New Haven: University of New Haven.

[15] Rosenblatt, R. (2003). Guns Control Opposing Views. New York: Greenhaven Press.

[16] Wilson, H. L. (2007). Guns, Gun Control, and Elections: The Politics and Policy of Gun Control. Lanham, Maryland: Rowan \& Littlefield Publishers Inc.

\footnotetext{
${ }^{22}$ Santa Fe New Mexican, Novermber 24, 1991, Santa Fe, New Mexico.

${ }^{23}$ Hutchinson News, February 3, 1998, Hutchinson, Kansas.
} 


\section{AUTHOR'S BIOGRAPHY}

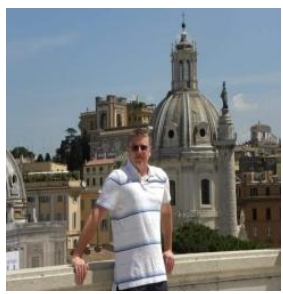

Nicholas J. Kethley, is an Adjunct Lecturer of History at Georgian Court University in Lakewood, NJ and Adjunct Associate Professor of History at Ocean County College in Toms River, NJ. Mr. Kethley has taught classes in Western Civilization, World Civilization and United States History. Mr. Kethley is also a former college lecturer at Rowan College at Burlington County and Strayer University. Mr. Kethley received his Master's degree in History at Monmouth University and his Bachelor's degree in History at Kean University.

Citation: Nicholas J Kethley. "American Appeal: Assault Weapons" International Journal of Humanities Social Sciences and Education (IJHSSE), vol 8, no. 6, 2021, pp. 30-36. doi: https://doi.org/10.20431/23490381.0806005.

Copyright: () 2021 Authors. This is an open-access article distributed under the terms of the Creative Commons Attribution License, which permits unrestricted use, distribution, and reproduction in any medium, provided the original author and source are credited. 